\title{
History of the Beaver Valley Labor History Society
}

\section{Tony Francschini \\ President, BVLHS}

The real history of the Beaver Valley Labor History Society is the story of two young, educated sons of working families.

Today, America is seeking new values and heroes. The cowboys and Indians, the John Waynes or the military heroes of the past have not served us well ... and is not Americana. If one will note, Vietnam has not produced one "hero." This mood has created a search for the real heroes and values of our country.

The Beaver Valley, rich in labor lore, is most fortunate to have two college-bred sons who burned with the desire to write the history of the Valley. They believe the history of the Valley is the history of America. That history is the untold and unrecorded story of labor's struggle to rise and to be recognized.

The two, like Christopher Columbus, set sail into unchartered waters. In their attempts to record the history of the Valley, they came close to foundering many times. The obstacles they encountered were many. Old taboos. Librarians whose purpose was to hide the past. Historical societies whose aim was to preserve their version of America.

Shifting courses many times, the young historians fastened onto a grant given to the Borough of Aliquippa, Pennsylvania, for labor history research. The authorities of the grant were a borough official and a local labor union officer. This proved to be a mistake. Although the two researchers were breezing along gathering invaluable research and producing a talk-slide show, they were accused of misusing grant money, writing embarrassing history, etc. The same old obstacles that they faced with librarians and historical societies cropped up. They lost control of their research and slides for their show.

Shifting course again, they sent out an SOS. An ex-steelworker, retired, responded. The three formed a good working team. Doors were opened to the past which led to interviews, a vast store of newspaper clippings and photographs, etc. Their previous research was recovered and they regained control. A new problem arose. Because they were subsidizing the project out of their pockets, begging and appealing for any help of any kind, a local university professor who was reproducing some of their discoveries was holding back on the 
release of the material. Again, someone else was in control. The team decided they needed complete autonomy. A decision was made to apply for a charter as a non profit organization. This would give them an identity, recognition and control.

The granting of the charter on Oct. 19, 1978 changed the shoebox operation into a legal entity, the Beaver Valley Labor History Society. This resolved the problem of control and released the two historians to renew their research. With that behind them, money became the priority. The Society adopted a fundraising plan-consisting of a short range and long range program.

(1) Seed money in the form of a raffle that provided, with each ticket sold, a dollar for day to day expenses. A few donations also trickled in. It also provided funds for expanding the collection of slides used in the talk-slide show. It paid for charter expenses. It paid for the first issue of the JOURNAL-almost, USWA 1211 bailed them out with a $\$ 100.00$ check.

(2) A mail fund raiser aimed at labor organizations and labor related individuals or groups. They are in the midst of this phase and it is a mild success offering hope for the future. Subscription fees for the JOURNAL are also a boost. Next year they intend to charge a membership fee.

(3) Soon, they will apply for government grants.

Great importance should be attached to the support and aid given by USWA 1211 and the Aliquippa Philip Murray Senior Citizen Club. They were always there when needed and never failed to help. In fact, the Society is going to share the Senior Citizens Building as soon as it is ready to be occupied.

Presently they are operating out of their homes (with a Post Office Box address) and meeting in a local ethnic club to conduct business.

Recently they discussed the possibility of expanding their charter to include "the preservation of buildings of historical significance." This will enable them to petition the proper authorities that any building scheduled to be razed should be preserved for the role it played in local labor history. They will make the restored building their home and show piece.

For further information and subscriptions to the Beaver Valley Labor History Journal, write Beaver Valley Labor History Society, Box 309, Aliquippa, Pa. 15001. 